\title{
Educative Supervision in International Cooperation Contexts
}

\author{
Ana Ortiz ${ }^{*}$, Pedro Valdivia-Moral ${ }^{2}$, Javier Cachón ${ }^{3}$, Joel Prieto ${ }^{4}$ \\ 'Department of Pedagogy, University of Jaén, Spain \{aortiz@ujaen.es\} \\ 2Department of Physical Education, University of Huelva, Spain \{pedro.valdivia@dempc.uhu.es\} (10) \\ ${ }^{3}$ Departament of Didactics of Music, Plastic and Corporal Expression, University of Jaén, Spain \\ \{icachon@ujaen.es\} \\ 4Departament of Education Science, Cardenal Herrera University, Spain \{joel manuel.prieto@uchceu.es\} \\ Received on 7 October 2014; revised on 7 October 2014; accepted on 22 October 2014; published on 15 January 2015 \\ DOI: 10.7821/naer.2015.1.98
}

\begin{abstract}
This present paper has got a clear goal: to contextualize education for development in the present moment, planning its evolution and the keys that characterize education collected from the most representative and up-to-date pieces of work. The experience that we present is integrated in a project developed in Paraguay that is expected to describe the professional characteristics of the school supervisors of the Republic of Paraguay and according to them, determine which are their training needs in order to establish the rules for the elaboration of a training programme that includes the guidelines that managers should know in order to exercise their role. The implementation of the abovementioned programme and the global evaluation of the project, complete the study with the second and third stages of the work. An empirical descriptive study of a transverse nature has been used. One of the conclusions worth mentioning is that two fifths of the supervisors have not received update course over the last three years and those who have taken it belong to very diverse areas.
\end{abstract}

KEYWORDS: EDUCATION FOR DEVELOPMENT, SUPERVISION, TRAINING NEEDS.

\section{INTRODUCTION}

This study is the first stage of a project developed in the Republic of Paraguay, funded by AECID, the Spanish Agency for International Development Cooperation (2007-2011), consisting of three stages. The present phase attempts to describe the professional features of school supervisors and to determine their training needs. For this purpose, this first section offers a review of the literature and a definition of concepts (development, education, cooperation, managerial role, Education for Development (hereinafter, ED); this is followed by the design of a training programme for managers which may contribute quality to their future role. The implementation of such programme and the global assessment of the project supplement this research, as the second and third stages of the work, where school violence plays a very important role.

\footnotetext{
*To whom correspondence should be addressed.

Facultad de Educación, Departamento de Expresión Musical, Plástica y Corporal

Campus Universitario La Cartuja, 18071.

Universidad de Granada, España.
}

Bandura (1983), Aber, L. et al. (1989), Boulton (1997), Baldry (1998), Abramobay and Rua (2002), Yubero and Navarro (2006), Nesdale (2007), Besley (2008), Costoya (2010), Sainio (2011), Buelga and Pons (2012), Boulton et al. (2014), Jones et al. (2014).

Over the last decades, the idea of development has evolved, since its beginnings as a merely geographical concept in the 1980s. In those times, according to the Spanish Coordinating Body for NGOs (CONGDE), the South was conceived of as poor and the North was seen as rich, or the origin of the term was based on the comparison between the economic situation in the North and in the South. In this respect, the Torres García Museum in Montevideo (Uruguay), has a ceramic item which shows the map of South America upside down, thus wondering what would happen if the South Pole was in the North and Ecuador was in the South.

Since the year 2000, an alternative view of the notion of development has emerged, within a global approach at a global society where inequality and injustice exist in all countries and in all continents. The degree of development of a country is no longer measured through its GDP, but through other indicators which regulate the welfare society: thus, even though there is an increase in GDP, this may not correlate with an improvement in well-being in a society. Such indicators are knowledge, training (Fernández Santamaría, 2003) and, in our opinion, education, as key factors in such development.

Development is not a static concept, but a dynamic, multidimensional one, just like societies. Years ago, we discussed "development aid", whereas now the focus is on cooperation, which inevitably must resort to education as a compulsory strategy.

Indeed, since the 1960s, education has gained a special role as a development factor, as has been recognised by various world conferences, such as, for instance, the $12^{\text {th }}$ Ibero-american Summit of Heads of State and Government, which was held in Cádiz. In this conference, it was clearly said that, in the early years of the 21th century, in the age of information and knowledge, information becomes the true protagonist: such education must be a quality one, as that envisaged by the 2021 Educational Goals of the Organization of Ibero-american States (OEI and Secretaría General Iberoamericana, 2008). This has been commented on by the Secretary General of the OEI, Álvaro Marchesi (2009) and confirmed by authors like Vargas, Tedesco and Rehem (2009) and Taille (2010). 
On the other hand, as has been shown at the University and Development Cooperation Conference held in Cádiz (2011), by the Andalusian University Cooperation Network (RACUA), education is a forgotten sphere within university cooperation, in spite of its relevance within cooperation actors and actions.

Therefore, building a society committed to the elimination of poverty and to sustainable human development must be necessarily accompanied by an educational process that trains and creates awareness and commitment towards development, under an ED model for global citizenship.

At present, education may be considered, within the sphere of development and cooperation, as a learning and training process addressed not only at "disadvantaged countries", but to all those countries where there are inequalities and injustice resulting from an excluding structure. This is why this type of education must become a tool for inclusion.

AECID (2009, p. 62) sees education as:

The constant (formal, non-formal and informal) educational process, which by means of knowledge, attitudes and values, aims to promote a global citizenship, generating a culture of solidarity committed to fight poverty and exclusion and to promote sustainable human growth. (our translation)

For Alba (2005, p. 65), education is "a set of activities of very diverse types aiming at building a culture of solidarity and social change towards a fairer world".

Celorio and López de Munain (2007) believe that ED is an educational process attempting to generate a critical awareness of the world situation and provide tools for social participation and change based on justice and solidarity. It aims to create a global critical citizenship, which is politically active and socially committed to fair and equitable human development for all communities in the world.

In practice, ED and cooperation share the same challenges: to build development models where all persons can live with dignity. This is why, within the sphere of cooperation, education must be based on the following principles (Mesa, 2009; CONGDE, 2005):

- The promotion of a mutual solidarity where ED is seen as an educational, participatory process, constantly changing and receiving feedback, where the various players continuously learn from common experience. Killen et al. (2013), Horne et al. (2007).

- The creation of North/South networks in the field of ED which may operate by strengthening bonds and facilitating common actions, willing to commit themselves especially to social justice and equality.

- ED is a political task seeking a structural, practical change in society, from the local to a global level.

- Development aid and cooperation is dependent on societal support; a conscious public opinion is required, committed to a more just world. This requires actions allowing midterm sensitization and education.

- The specific nature of ED lies in its bonds with the South and with the discourses and proposals put forward by social and development organizations in Africa, Latin America and Asia.

- ED is part of a non-traditional educational approach, based on the educational contributions by Freire $(1967,2000)$,
Piaget (1977, 1981), Vigotski (1980), Bruner (1991) and action-oriented research.

- It is and social and political type of education, guided by social justice, trying to develop an awareness of global inequalities in the distribution of power and wealth, its causes and consequences, and the role of the North in the achievement of more just structures.

- Education must promote an awareness of living in an interconnected world, whose dynamism may not be understood in a local way, but as a constantly changing global system of knowledge, capabilities and values.

Education, as a development strategy alongside cooperation, must combine four dimensions: sensitization, training, research and mobilization.

Cooperation must seek efficacy and efficiency, and develop an interest in decentralization and the role played by civil societies. These issues are not exclusive to cooperation, but can also be found in emancipating, critical educational processes, such as ED, where the role of families is a crucial one (Dekovic, Wissink and Meijer, 2004), as also is the teacher's authority (Espot, 2010). As Beltrán has pointed out (2013), education must be universal (education for all), global (we live in a globalized world), a priority (it should rank first in governments' agendas) and democratic (education provides equal opportunities and reduces differences based on origin).

On the other hand, exercising a managerial role implies the development of capabilities and skills allowing persons to guide themselves by participation, implementation and promotion of cooperative work; such are the pillars of the educational system, where the role of the manager is a key factor in order to attain its purposes and goals. Therefore, there is a need for managers who are well trained regarding capabilities and skills, so that they can act as dynamic forces within the educational system.

This is why it is necessary to determine the real training needs of managers, depending on the requirements of each country, in order to draft a training proposal: thus, this work should help to develop a conceptual theoretical framework on managers, their role, the nature of their work and their actions, in order to give more autonomy to educational institutions (Almazán, 2011, p. 20). This diagnosis is an important one, both in education and in other fields, such as healthcare (Urdaneta and Urdaneta, 2013).

\section{OBJECTIVES}

The general objective is to determine the professional characteristics of school supervisors as agents for innovation in the educational system.

The specific goals for the first stage of this study are the following:

(1) Analysing, describing and defining the role of school supervisors regarding their role as innovation promoters in educational institutions in Paraguay.

(2) Contributing solutions to the professional characteristics of school supervisors and their influence on the promotion of innovation in educational institutions.

The specific goals for the second stage of this study are the following:

(1) Detecting the training needs of school supervisors and classifying them into real, perceived and potential needs. 
(2) Putting forward proposals for the creation of training programmes for school supervisors.

\section{METHOD}

\subsection{Design}

This research is formulated as an empirical, descriptive, transverse study, which is divided into two separate stages in order to make the work easier. The first stage consists in collecting information on the professional characteristics of school supervisors in Paraguay, and the second attempts to determine what their training needs are, according to their perceptions, weaknesses and points of view.

In order to obtain the information, a questionnaire was used as a quantitative methods (Paraguay School Supervisors Questionnaire, hereinafter CSEP), which was designed for these purposes, based on a Likert-type response scale. Also, an interview was held with a group of school supervisors, in order to collect information for the development of the questionnaires.

\subsection{Population and Sample}

The research subjects are the administrative and school supervisors of the Republic of Paraguay. The total population includes $\mathrm{N}=369$ subjects, from 16 provinces (Departamentos), from whom a representative sample (as a probability sample) has been taken, with a total of $n=120$ supervisors, i.e. $32.5 \%$ of the sample.

The selected sample has answered six questions, in order to identify individuals concerning sex, age, position held, department they belong to, years of service as supervisors and as teachers, as is shown in the five bar charts below. Thus, the results regarding sex indicate that the sample consisted of 80 women and 34 men, with 6 respondents who did not give an answer to this item. As for age, 78 individuals were over 40 years of age, 39 were between 30 and 40 years old, 1 was below thirty and 2 subjects did not answer. Also, 41 individuals held a post as administrative supervisors, whereas 75 were pedagogical supervisors, with 4 subjects not answering this question. The results regarding supervisors' experience show that 67 individuals had between 1 and 5 years' experience, 34 of them between 6 and 10 years, 5 between 16 and 20 years, seven respondents had over 20 years' experience, and 2 did not answer. Finally, the teaching experience was also analysed, the results being: over 20 years' experience for 36 respondents, between 16 and 20 years for 43 respondents, between 11 and 15 years for 22 persons, between 6 and 10 years for 11 subjects, and between 1 and 5 for 2 respondents, whereas 6 individuals did not answer this question. The geographical distribution of the sample is shown in Figure 1.

\subsection{Instrument}

The instrument used is the CSEP questionnaire, consisting of 38 items, grouped into the four dimensions which we shall now explain here:

- Training Function: it attempts to find out about the present training of school supervisors with respect to specific training in school management over the past three years, the specialized areas of greater interest and the knowledge they possess.

- Professional Function: it includes issues related to management, coordination, execution and training, implementation and training activities.
- Supervision Function: it contains information on the role played by each school supervisor and the degree of satisfaction derived from his or her task.

- Interpersonal Relationships: it proposes a set of items attempting to describe the relationships between supervisors and teaching staff.

Table 1. School supervisors Questionnaire

\begin{tabular}{ll}
\hline Dimension & No. of items \\
\hline Training & 11 \\
Professional & 10 \\
Supervision & 8 \\
Interpersonal Relationships & 10 \\
\hline
\end{tabular}

In order to design the CSEP questionnaire, the following stages were followed:

(1) Review of the literature on the subject matter, in order to become familiar with the state of the art.

(2) Contextualize the study in the country and the population envisaged.

(3) Interview with school supervisors.

(4) On the basis of the data obtained, design of the questionnaire.

(5) Experts' meeting (5 Paraguayan and 8 Spanish members) for questionnaire assessment.

(6) Application of questionnaire to a small sample in order to evaluate comprehension (pre-test).

(7) Design of final version of questionnaire based on experts' suggestions and the pre-test. More specifically, Paraguayan terminology was applied to questions appearing in the identification section, such as the position held and the academic background.

\subsection{Procedure}

Once the questionnaire was applied to the selected sample, the data were processed with the Windows SPSS v.19 statistical package, and the statistics were performed in order to validate the results.

In order to asses questionnaire reliability, Cronbach's internal consistency coefficient was used. The value obtained was .805 , which indicates a satisfactory internal consistency, since the value is over. 70 .

\section{RESULTS}

The results shown below are shown in terms of frequency and percentage. $80.8 \%$ of respondents state they received training as teachers, whereas $19.2 \%$ did not answer. The teaching training of school supervisors is distributed as follows: 
Table 2. Training background as teachers

\begin{tabular}{lll}
\hline Training & Frequency & Percentage \\
\hline $\begin{array}{l}\text { Training for Basic School Education (1st } \\
\quad \text { and 2nd cycle) }\end{array}$ & 57 & 47,5 \\
$\quad \begin{array}{l}\text { Training for Secondary Education } \\
\text { Training for Basic School Education (1st, }\end{array}$ & 5 & 4,2 \\
$\quad$ 2nd and 3rd cycle) & 2 & 1,7 \\
$\quad \begin{array}{l}\text { Training for Basic School Education (1st } \\
\quad \text { and 2nd cycle) and Secondary Educa- }\end{array}$ & 20 & 16,7 \\
$\quad$ tion & 1 & \\
$\quad$ Training for Initial Education and Basic & & 0,8 \\
$\quad$ School Education (1st and 2nd cycle) & 4 & 3,3 \\
$\quad$ Social Studies Teacher & 1 & 0,8 \\
$\quad$ Language Teacher & 2 & 1,7 \\
$\quad$ Guarani Teacher & 2 & 1,7 \\
Mathematics Teacher & 3 & 2,5 \\
$\quad$ No training & & \\
\hline
\end{tabular}

As can be observed in Table 1, the highest figures (57) correspond to professionals trained for $1^{\text {st }}$ and $2^{\text {nd }}$ cycle of Basic Secondary Education (EEB), 5 for Secondary Education, 2 for EEB up to $3^{\text {rd }}$ cycle, 20 received training for $1^{\text {st }}$ and $2^{\text {nd }}$ Cycle EEB and Secondary Education, only 1 for Initial Education and $1^{\text {st }}$ and $2^{\text {nd }}$ cycle EEB, while the rest were trained for more specific teaching: 4 as Social Studies teachers, 1 as a language teacher, 2 as a Guarani Teacher, 2 as Mathematics teachers and 3 had not received any training.

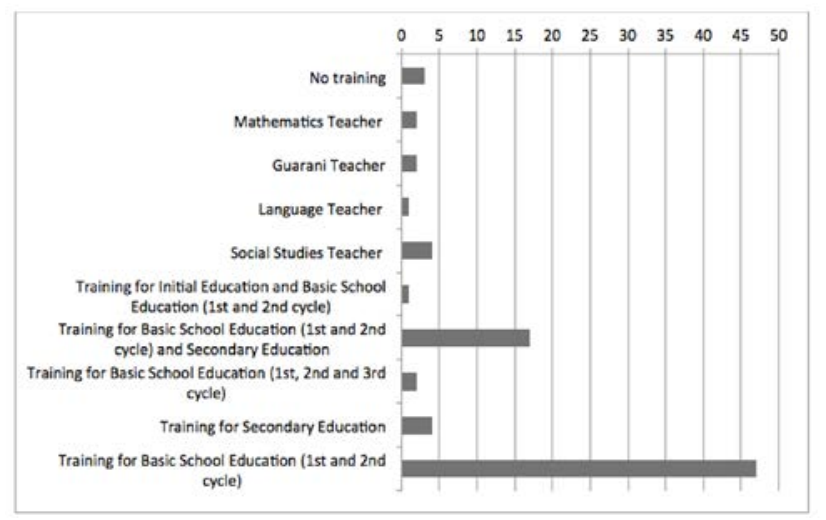

Figure 1. Teacher training among the Supervisors in the survey

Regarding the Training (academic) Function, and as may be seen in Figure 2, the descriptive statistics indicate that $80.8 \%$ of respondents say they possess more or less specialized training: $50.8 \%$ say they possess specialized academic training, compared to $49.2 \%$ who say they do not have it. $30 \%$ state they have completed postgraduate masters' training, whereas $70 \%$ did not do any postgraduate studies. There is no school supervisor in possession of a doctorate.

Slightly less than half of the respondents (45.8\%) believe that the knowledge they possess is insufficient. Such percentage is lower among women (55.9\%) and decreases with age (44.8\%) among supervisors over 40 years old.

Almost one third of the respondents (32.5\%) confess to having a low degree of expertise concerning new technologies, while $10.8 \%$ appear to be indifferent. Men believe they have a higher knowledge (58.8\%) than women (53.8\%). Such knowledge is higher as a result of more years of experience.

$83.4 \%$ of respondents consider that they need training in order to improve the curriculum proposals they put forward. This need is more visible among men (94.1\%) than among women (86.3\%) and among supervisors with less years of experience.

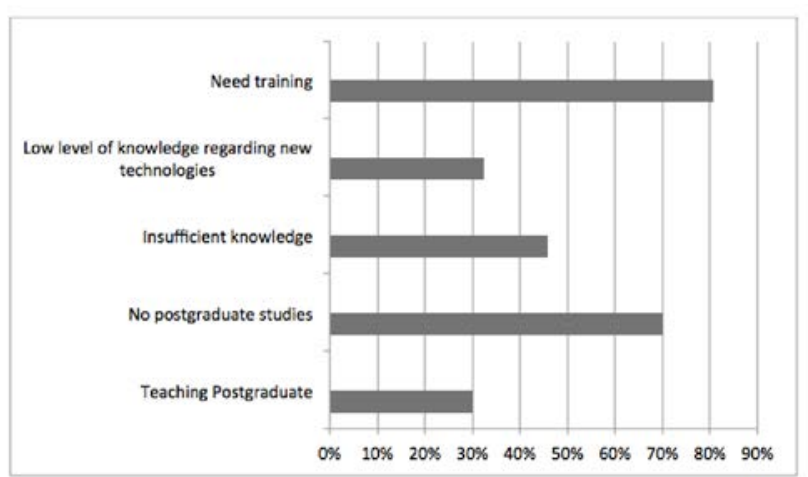

Figure 2. Training Function

Concerning their Professional Function (see Figure 3), 90.9\% have very clear goals; within such percentage, women are more in agreement with this view. Such opinion also increases with years of supervising experience. $36.6 \%$ of respondents state they possess a low degree of knowledge regarding educational plans and programmes. This perception increases with years of experience (probably as a result of the scarce number of specialization courses received). Again, women say they have a higher degree of knowledge than men in this area $(61.3 \%$ disagree with the statement in the item, compared to $44.1 \%$ of men).

Supervisors have a profound knowledge of the regulatory framework (85.8\%), although such knowledge is greater among men $(91.1 \%)$ than among women $(83.8 \%)$, and is also greater among respondents with 11 to 15 years' experience.

As regards the training needs of teachers, three out of four school supervisors $(78.4 \%)$ are aware of them. The percentage is greater among women (81.3\%) than among men (73.5\%). The lack of knowledge increases with the years of experience.

$65.9 \%$ of respondents consider that they should pay more attention to pedagogical problems. Such is the case especially among men (73.5\%) rather than among women (62.5\%). This belief increases with the years of experience as supervisors.

$41.7 \%$ of respondents are critical about their work performance, whereas $6.7 \%$ are indifferent. Men are more critical of their own work (47.1\%) than women (42.3\%). Also, supervisors with more years of experience are less critical of their own performance.

There is a clear desire of constant improvement among school supervisors, as stated by $82.5 \%$ of respondents. This percentage is slightly higher among women (86.3\%) than among men (82.3\%), and among supervisors with 1 and 5 years' experience.

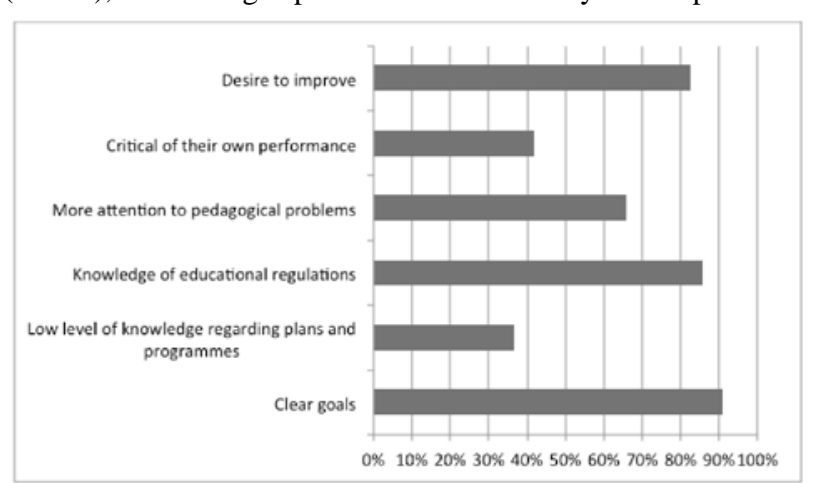

Figure 3. Professional Function 
When analysing the Supervising Function (Figure 4), it was found that school supervisors are very sensitive towards teacher training (87.5\%). There are no significant differences according to sex or years of supervising experience. They plan their professional task (92.5\%) with no significant sex differences; however, those respondents with less experience in their role are more fond of planning. The same percentage believe they provide guidelines to teachers, with no significant differences resulting from age or experience as supervisors.

The level of participation expressed by school supervisors in the management and organization of their institutions is very high (94.2\%), again with no significant differences regarding sex or experience as supervisors.

$71.7 \%$ of respondents apply assessment tools in order to evaluate students' learning. Men are more likely to apply student assessment tools (76.5\%), than women (68.8\%). There are no significant differences corresponding to the years of experience as supervisors.

82.5\% of supervisors implement plans with the participation of head teachers. Women are more inclined towards participation (83.8\%) than women (79.4\%), although the difference is not significant. Neither is there any difference based on years of experience as supervisors.

$85 \%$ of supervisors admit that they must improve their knowledge of educational management techniques; the perception of this need is the same among men and women. Also, this need increases among supervisors with less experience.

Most respondents state that they perform a self-assessment of their work (95\%), with no significant differences according to sex or supervising experience. They believe that the working methods they use promote the development of basic skills among teachers (88.4\%). This perception is greater among men (94.1\%) than among women (86.3\%) and also among supervisors with less experience.

$90 \%$ of supervisors consider that they possess and apply leadership skills, with no significant differences according to sex or supervising experience.

$94.1 \%$ of respondents believe that they motivate and provide support to teachers. This attitude is more present among men and among supervisors with 10-20 years' experience.

Most supervisors say that they are satisfied with the task they perform (89.2\%), with no significant sex differences. Supervisors with over twenty years' experience in their posts are those less satisfied with their work. Most supervisors (84.2\%) believe that their tasks are clearly defined, again with no differences according to sex or years of experience as supervisors.

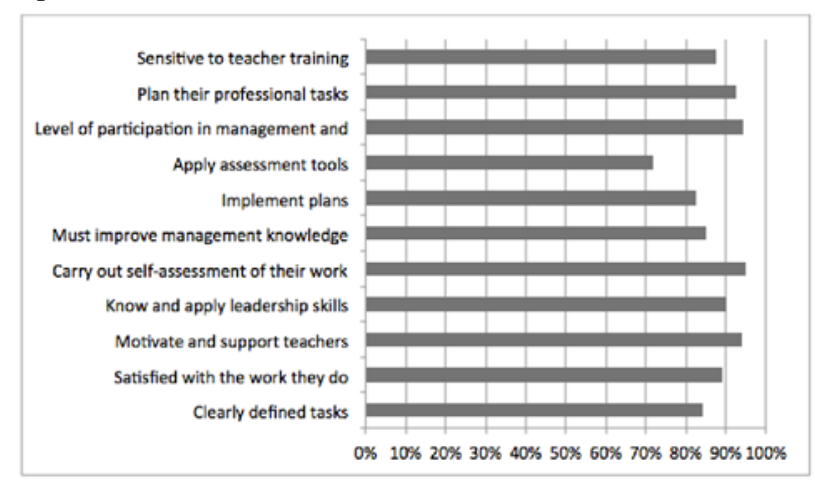

Figure 4. Supervising function
From the analysis of the Interpersonal Function (Figure 5), it may be observed that supervisors agree (95\%) that they promote an open, interactive atmosphere among teachers. They show an open attitude, ready to listen to any suggestion by teachers (89.2\%), although $31.7 \%$ of them admit that it is necessary to improve such relationships and $8.3 \%$ are indifferent to this issue. They also believe that they are ready to solve conflict situations that may arise (88.4\%).

$95.8 \%$ of respondents consider that they recognize and value the efforts made by teachers; this feeling is more visible among men. $91.7 \%$ encourage teachers to contribute ideas and suggestions. This is more widespread among men than among women, although in general there are no significant differences according to sex or experience as supervisors.

Most supervisors (84.2\%) believe that they work is clearly defined. They make decisions taking into account the consequences such decisions may have among teachers (90\%). In this case there is a lower percentage among women, whereas there are no differences according to years of experience as supervisors.

$90 \%$ are against authoritarian acts; this is the case especially among men (97\%), more than women (86.3\%). This percentage increases with the years of experience, which has a positive influence upon interpersonal relationships.

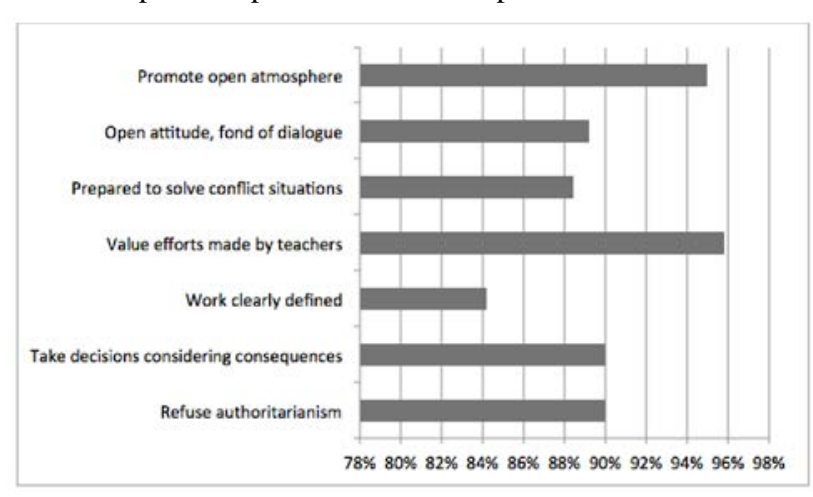

Figure 5. Interpersonal Function

\section{CONCLUSIONS}

In response to the goals envisaged and the four dimensions studied (training, professional, supervising function and relationship with teaching staff they are responsible for), the conclusions are the following:

(1) The professional characteristics of school supervisors as the promoters of innovation in the Paraguayan educational system are: women (mostly), over 40 years of age, pedagogists (there are fewer administrative supervisors), belonging to the central province (Asunción and surroundings), with 1 to 5 years' supervising experience and over 15 years' experience as teachers, with training for $1^{\text {st }}$ and $2^{\text {nd }}$ cycle Basic Education, and specific teacher training linked to Educational Administration.

(2) The typical profile of supervisors in Paraguay is that of graduates, mainly in Pedagogy/Education Sciences.

(3) Supervisors are aware of the training needs of the teachers they are responsible for, they plan their professional tasks, believe it necessary to promote cooperation among their colleagues, and state that their 
supervising practice does not conform to traditional models.

(4) These specialists have an open attitude with, and are ready to listen to teachers, encouraging staff to contribute ideas and suggestions, although one third believe it necessary to improve their relationship with teachers. They consider they are suitably prepared to solve conflict situations which may arise, although they refuse to act in an authoritarian way.

(5) The supervisors are satisfied with the work they do, motivate their teachers, are convinced that they are fulfilling their role responsibly, and have a desire to improve. They consider they are suitably prepared to solve conflict situations which may arise, although they refuse to act in an authoritarian way.

(6) Two-fifths of supervisors have not received any updating course over the past three years, and those who have belong to very diverse areas. Half of them confess that they do not possess sufficient knowledge to fulfil their role.

(7) Supervisors request training, mainly in educational supervision, information and communication technologies, educational policies and educational research. Almost all of them believe that they need training in order to improve the curriculum proposals they put forward

(8) A wide majority of supervisors believe that they should devote more time to pedagogical problems, which would require training courses with enough practice stages in order to obtained the desired results.

\section{REFERENCES}

Agencia Española de Cooperación Internacional para el Desarrollo (AECID) (2009). III Plan Director de Cooperación Española 2009-2012. Retrieved from AECID webpage

http://www.aecid.es/export/sites/default/web/galerias/publicaciones/descargas/ Plan_Director_2009-2012.pdf

Alba, N. (2005). Educación para el Desarrollo ¿una oportunidad para cambiar la educación?. Investigación en la Escuela, 65, 63-71.

Almazán, L. (2011). La supervisión educativa en contextos de cooperación internacional. Jaén: Servicio de Publicaciones de la Universidad de Jaén.

Aber, L., Allen, J., Carlson, V., \& Cichetti, D. (1989). The effects of maltreatment on development during early childhood: recent studies and their theoretical, clinical and policy implications. In D. Cichetti \& V. Carlson (Eds.), Child maltreatment (pp. 579-620). Cambridge, Mass: Cambridge University Press. doi: 10.1017/CBO9780511665707.019

Abramobay, M., \& Rua, M. das G. (2002). Violences in the Schools. Basilea: UNESCO.

Baldry, A. C. (1998). Bullying among Italian Middle School Students. School Psychology International, 19(4), 361-374. doi: 10.1177/0143034398194007

Bandura, A. (1983). Psychological mechanisms of aggression. In R. G. Geen \& E. I. Donnerstein (Eds.), Aggression: Theoretical and empirical reviews (vol. 1, pp. 1-40). New York: Academic Press.

Beltrán, J. (2013). La educación como cambio. Revista Española de Pedagogía, $254,11-27$.

Besley, B. (2008). Cyberbullying: An Emerging Threat to the "always on" Generation. Canadian Teacher Magazine, 18-20.

Boulton, M. (1997). Teacher's view on bullying: definitions, attitudes and ability to cope. British Journal of Educational Psychology, 67, 223-233. doi: 10.1111/j.2044-8279.1997.tb01239.x

Boulton, M. J., Hardcastle, K., Down, J., Simmonds, J., \& Fowles, J. A. (2014). A comparison of pre-service teachers' responses to cyber versus traditional bullying scenarios: similarities and differences and implications for practice. Journal of Teacher Education, 65(2), 145-155. doi: 10.1177/0022487113511496

Bruner, Jerome (1991). Actos de significado. Más allá de la revolución cognitiva. Madrid: Alianza Editorial.
Buelga, S., \& Pons, J. (2012). Agresiones entre adolescentes a través del teléfono móvil y de Internet. Psychosocial Intervention, 21(1), 91-102. doi: 10.5093/in2012v21n1a2

Celorio, G., \& López de Munain, A. (2007). La educación transformadora ante los retos de la globalización. Actas del III Congreso de Educación para el Desarrollo. Bilbao: España.

Coordinadora de la ONG para el Desarrollo-España, CONGDE (2005). La educación para el desarrollo. Una estrategia de cooperación imprescindible. Madrid: CONGDE.

Costoya, M. G. (Coord.) (2010). La violencia en las escuelas: Un levantamiento desde la mirada de los alumnos II. San Martín, Argentina: Ministerio de la Nación, UNSAM (Universidad Nacional de San Martín, Argentina).

Dekovic, M., Wissink, I. B., \& Meijer, A. M. (2004). The role of family and peer relations in adolescent antisocial behaviour: comparison of four ethnic groups. Journal of Adolescence, 27, 497-514. doi: 10.1016/j.adolescence.2004.06.010

Espot, M. R. (2010). Reforzar la autoridad del profesor. La Vall, 14, 31-32.

Fernández Santamaría, M. R. (2003). La situación de la educación básica en Iberoamérica: retos para la cooperación internacional. Revista iberoamericana de Educación, 31, 145-167.

Freire, P. (1967). Educação como prática da liberdade. Río de Janeiro: Paz e Terra.

Freire, P. (2000). Pedagogia da indignação - cartas pedagógicas e outros escritos. São Paulo: UNESP.

Killen, M., Mulvey, K. L., \& Hitti, A. (2013). Social Exclusion in Childhood: A Developmental Intergroup Perspective. Child Development, 84 (3), 772-790. doi: 10.1111/cdev.12012

Horne, A. M., Stoddard, J. L., \& Bell, C. D. (2007). Group approaches to reducing aggression and bullying in school. Group Dynamics - Theory, Research and Practice, 11(4), 262-271. doi: 10.1037/1089-2699.11.4.262

Jones, S.E.; Manstead, A.S.R. \& Livingstone, A.G. (2014). Bullying and Belonging: Teachers' Reports of School Aggression, Frontline Learning Research, 2 (5), 26-45.

Marchesi, A. (2009). Las Metas Educativas 2021. Un proyecto iberoamericano para transformar la educación en la década de los bicentenarios. Revista Iberoamericana de Ciencia, Tecnología y Sociedad, 12(4), 87-157.

Mesa, M. (2000). La educación para el desarrollo: entre la caridad y la ciudadanía global. Papeles de Cuestiones Internacionales, 70, 11-26.

Mesa, M. (2009). La educación para el desarrollo: un ámbito estratégico para la cooperación al desarrollo. Madrid: CIDEAL.

Nesdale, D. (2007). Peer groups and children's school bullying: Scapegoating and other group processes. European Journal of Developmental Psychology, 4, 388-392. doi: 10.1080/17405620701530339

Organización Estados Iberoamericanos y Secretaría General Iberoamericana (2008). Metas Educativas 2021: la educación que queremos para la generación de los bicentenarios. Madrid: OEI.

Piaget, J. (1977). Essay on necessity. Human Development, 29, 301-14. doi: $10.1159 / 000273106$

Piaget, J. (1981). Le possible et le necessarie L'evolution des possibles chez l'enfant. Paris: Presses Universitaires de France.

Red Andaluza de Cooperación Universitaria, RACU (2011, April). La cooperación universitaria al desarrollo ante los retos de un mundo en crisis. V Congreso Universidad y Cooperación al Desarrollo. Cádiz.

Rehem, Cl. (2009). Gestión de centros formativos del siglo XXI. Nuevas miradas, nuevos abordajes. In A. Blas \& J. Planells (Coords.), Los retos actuales de la educación técnico-profesional. Madrid: OEI.

Sainio, M., Veenstra, R., Huitsing, G., \& Salmivalli, C. (2011). Victims and their defenders: A dyadic approach. International Journal for Behavioral Development, 35, 144-151. doi: 10.1177/0165025410378068

Taille, Y. (2012). La deliberación moral. In B. Toro \& A. Tallone (Coords.), Educación, valores y ciudadanía. Madrid: Bejomi.

Tedesco, J. C. (2009). Los temas de la agenda sobre gobierno y dirección de los sistemas educativos en América Latina. In A. Marchesi, J. C. Tedesco \& C. Coll (Coords.), Calidad, equidad y reformas en la enseñanza. Madrid: OEI.

Urdaneta, O., \& Urdaneta, M. (2013). Evaluación del desempeño y motivación del personal en los institutos de investigaciones en salud. Revista de Ciencias Sociales, 19(4), 672-682.

Vargas, F. (2009). Escenarios y tendencias en el mundo del trabajo y de la educación en el inicio del siglo XXI: el nuevo paradigma del Aprendizaje a lo largo de la vida y la sociedad del conocimiento. F. de A. Blas \& J. Planells (Coords.), Los retos actuales de la educación técnico-profesional. Madrid: OEI.

Vigotski, L. S. (1980). El estructuralismo. Barcelona: Oikos-Tau.

Yubero, S., \& Navarro, R. (2006). Student's and teachers' views of gender-related aspects of aggression. School Psychology International, 27, 488-512. doi: 10.1177/0143034306070436 